\title{
The Pull-out Capacity of Suction Caissons in Model Investigations
}

\section{Andrzej Sawicki, Lukasz Wachowski, Marek Kulczykowski*}

Institute of Hydro-Engineering, Polish Academy of Sciences, Kościerska 7, 80-328 Gdańsk, Poland, ${ }^{*}$ Corresponding author, e-mail: marekkulczykowski@ibwpan.gda.pl

(Received October 21, 2016; revised January 16, 2017)

\begin{abstract}
A small-scale model experiment on the pull-out resistance of suction caissons is described. The pull-out force and suction developed within the caisson in the extraction process were recorded during the experiment. A simple breakout model, together with an elementary static formulae, is applied to predict the results obtained experimentally. There is a reasonably good agreement between the experimental results and predictions. An extensive discussion of the approach applied is included. The analysis presented in this paper is original, as it differs from other approaches mentioned in this paper, and leads to acceptable predictions. At the end, the results are also compared with another approach for predicting the capacity of suction caissons.
\end{abstract}

Key words: suction caissons, pull-out resistance, model investigations

\section{List of symbols}
a - pressure factor;
$D_{i} \quad$ - inside caisson diameter;
$D_{o} \quad-\quad$ outside caisson diameter;
$D_{10} \quad$ - effective particle diameter of soil;
$D_{60} \quad$ - grain diameter at $60 \%$;
$e_{\min }-$ void ratio of soil in its loosest state;
$e_{\max }-$ void ratio of soil in its densest state;
$F \quad-$ dimensionless factor;
$G_{c} \quad-$ own weight of caisson;
$G_{c s} \quad-$ total weight of caisson with extracted soil;
$G_{s} \quad-$ weight of extracted soil;
$G_{c}^{\prime} \quad$ - buoyant own weight of caisson;
$G_{p}^{\prime} \quad-$ buoyant own weight of plate;
$G_{s}^{\prime} \quad-$ buoyant weight of extracted soil reduced by the seepage;
$h \quad-\quad$ inner caisson height; 


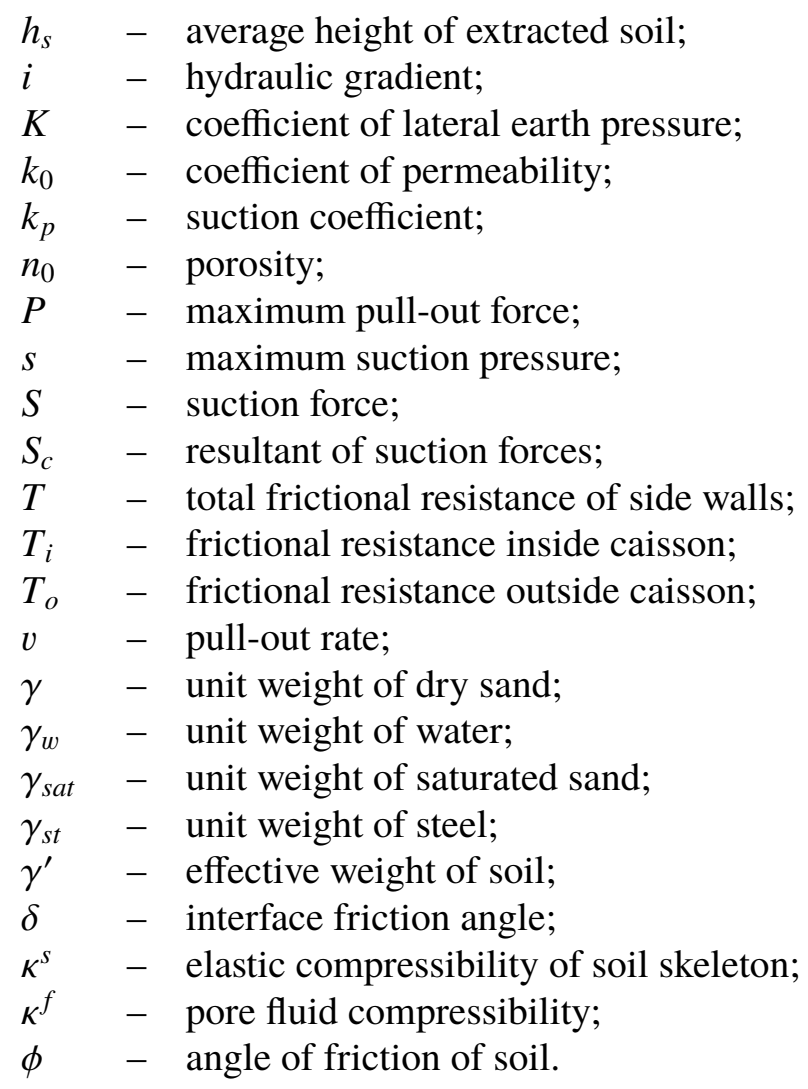

\section{Introduction}

Suction caissons are modern technological solutions in geotechnical engineering, particularly useful in marine and offshore engineering, where loadings applied to structures vary, even in terms of direction. Sometimes, the resultant force may press the foundation down into the seabed, whereas in another case, the resultant force may pull it out of the subsoil. The mechanics of the pull-out phenomenon is not yet well elaborated, although there exist a number of publications.

Some introduction to the suction caissons technology can be found in Internet publications, see NGI (I, II). Applications of suction caissons as foundations for offshore wind turbines are described in (Patel and Singh 2012) and in (Jara 2009). Villalobos (in 2007) presents some problems related to the installation of suction caissons in sand, and Houlsby and Byrne (in 2005) propose appropriate design procedures. Various geotechnical procedures and analyses for the installation of suction caissons are also presented in (Byrne and Houlsby 2002, Zeinoddini and Nabipour 2009 and Gabr et al 2015). Special attention is devoted to suction caissons founded in clay, see (Houlsby et al 2005, Chen and Randolph 2007, Huang et al 2003 or Cao et al 2002). 
Most of the papers are concerned with the installation of suction caissons in the seabed. A simple but extensive theory for predicting the tensile capacity of a suction caisson is presented in (Houlsby et al 2005). They consider a number of different failure modes and propose appropriate calculation procedures for capacities.

This paper deals with the pull-out resistance of suction caissons, investigated in small-scale experiments performed in the geotechnical laboratory of the Institute of Hydro-Engineering (IBW PAN). The maximum pull-out force and suction pressure in the extraction process are measured.

In the paper, a new original approach to the pull-out capacity of suction caissons is also described. A simple theory based on the mechanics of the breakout phenomenon, see (Sawicki 1995 or Sawicki and Mierczyński 2003), is proposed. This new method is original, as it differs from the approach presented in the publication of Houlsby et al (2005).

The experimental results are compared with theoretical predictions derived from a simple model of breakout and with the solution proposed by Houlsby, Kelly and Byrne.

\section{Description of experiment}

A small-scale model experiment on the pull-out resistance of suction caissons was performed in the geotechnical laboratory of IBW PAN. The experiment was conducted in a container filled with sand and water. A model of the caisson foundation was installed in a fully saturated soil and then pulled-out at a constant extraction rate. The pull-out force and suction developed within the caisson were recorded simultaneously during the test. The basic idea of this small-scale experiment is shown in Fig. 1.

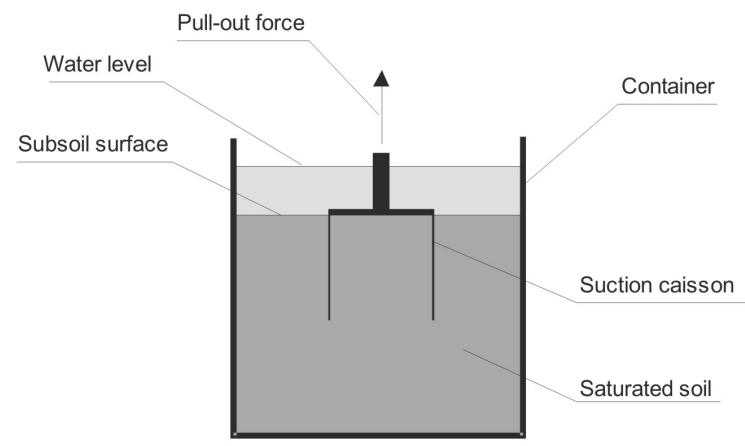

Fig. 1. The basic idea of small-scale model experiments on the pull-out resistance of suction caisson

A circular steel model caisson was used in the experiment (see Fig. 2). The caisson foundation was $100 \mathrm{~mm}$ in the outside diameter $D_{o}$ with the inner height $h$ of $100 \mathrm{~mm}$. The wall (skirt) thickness was $1.5 \mathrm{~mm}$, so the inside diameter $D_{i}$ was $97 \mathrm{~mm}$. The thickness of the upper plate of the caisson was $6 \mathrm{~mm}$, so the total high of the model 


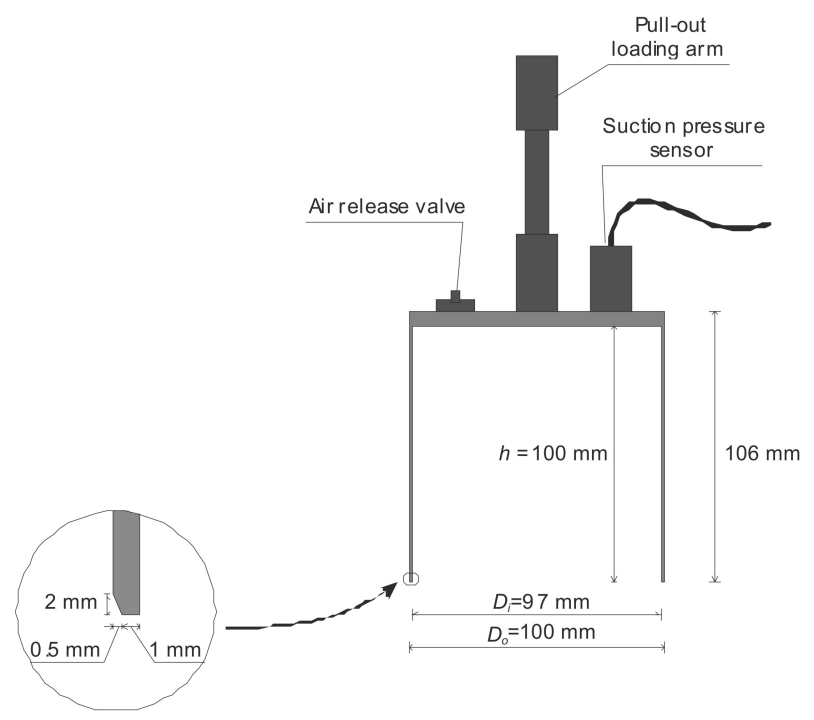

Fig. 2. A small-scale model of a suction caisson

was $106 \mathrm{~mm}$. The end of the skirt was slightly beveled on the outside. The upper plate was equipped with a valve for excess air pressure to dissipate during installation and a pressure transducer. A miniature pore water pressure sensor with a sintered bronze filter was used for the measurement of suction inside the model. The filter of the sensor was fully saturated before the experiment. The caisson was connected to a vertical pull-out loading arm with a force gauge. The own weight of this model was $G_{c}=9.6 \mathrm{~N}$.

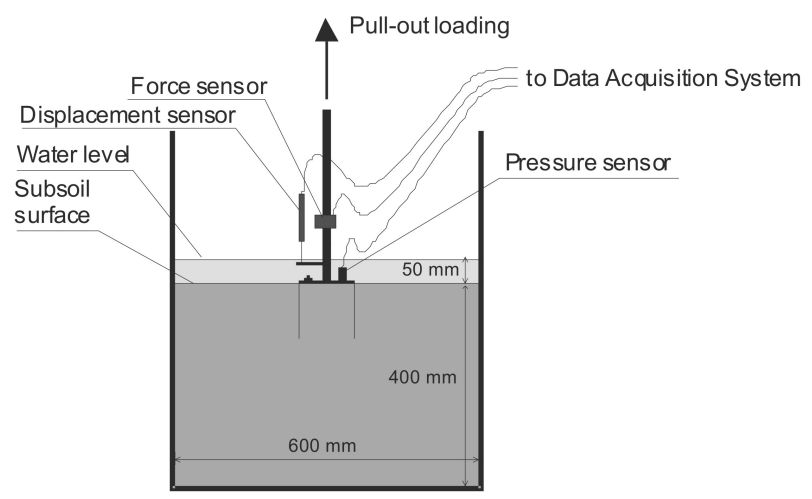

Fig. 3. The test setup and the measurement system

The experiment was performed in a tank of diameter $600 \mathrm{~mm}$ and depth $700 \mathrm{~mm}$ filled with saturated fine sand. The soil deposit was $400 \mathrm{~mm}$ in height, and a water column of $50 \mathrm{~mm}$ was maintained above the sand surface. A diagram of the test setup 
used in the experiment is presented in Figure 3. A photograph of the model before extraction is shown in Figure 4.

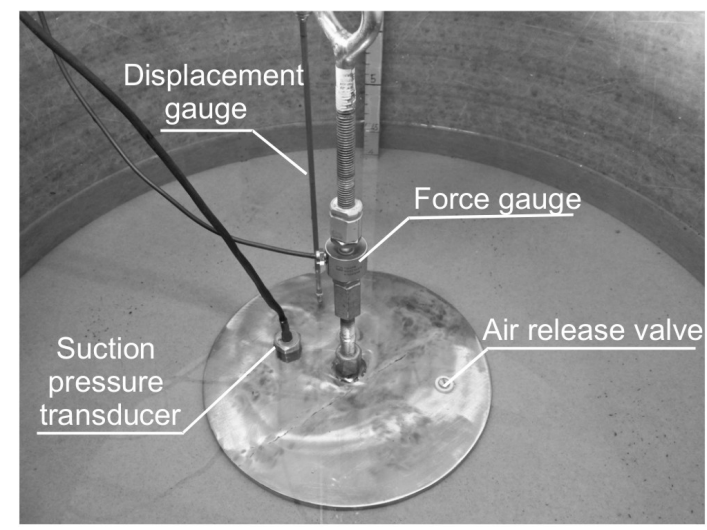

Fig. 4. The caisson model in the test container with measurement transducers

The sand used was the "Lubiatowo" non-cohesive fine silica sand. The density of dry sand was determined by measuring the weight and volume of a sample. The same procedure was applied in determining the density of saturated soil. The value of the angle of friction $\phi$ was obtained in a triaxial test. The interface friction angle $\delta$ between the caisson wall and the soil was determined with a direct shear apparatus. The geotechnical properties of the model sand are summarized in Table 1.

Table 1. Properties of the "Lubiatowo" sand

\begin{tabular}{|l|c|}
\hline$D_{10}$ & $0.15 \mathrm{~mm}$ \\
\hline$D_{60}$ & $0.20 \mathrm{~mm}$ \\
\hline Unit weight of sand grains & $25.8 \mathrm{kN} / \mathrm{m}^{3}$ \\
\hline Unit weight of dry sand $\gamma$ & $15.8 \mathrm{kN} / \mathrm{m}^{3}$ \\
\hline Unit weight of saturated sand $\gamma_{\text {sat }}$ & $19.7 \mathrm{kN} / \mathrm{m}^{3}$ \\
\hline Internal friction angle $\phi$ & $34.0^{\circ}$ \\
\hline Friction angle between the soil and the model wall $\delta$ & $9.7^{\circ}$ \\
\hline Porosity $n_{0}$ & $39 \%$ \\
\hline Void ratio $e_{\min }$ & 0.55 \\
\hline Void ratio $e_{\max }$ & 0.82 \\
\hline Coefficient of permeability $k_{0}$ & $1.54 \times 10^{-3} \mathrm{~m} / \mathrm{s}$ \\
\hline
\end{tabular}

Before a pull-out test, the container was filled with water, and then the sand was rained from the top. Next, the model was installed in the saturated subsoil with an open valve to release the air closed in the caisson. When the lid of the model had reached the subsoil surface, the valve was closed, and an axially-symmetric pull-out force was applied. The extraction rate was $20 \mathrm{~mm} / \mathrm{s}$. During the pull-out process, the pull-out force, the suction pressure inside the model, and the displacement of the caisson were 
recorded. The process of extraction was relatively rapid, lasting about 3 seconds. The test results are presented in Figs. 5, 6, 7 and 8, and summarized in Table 2.

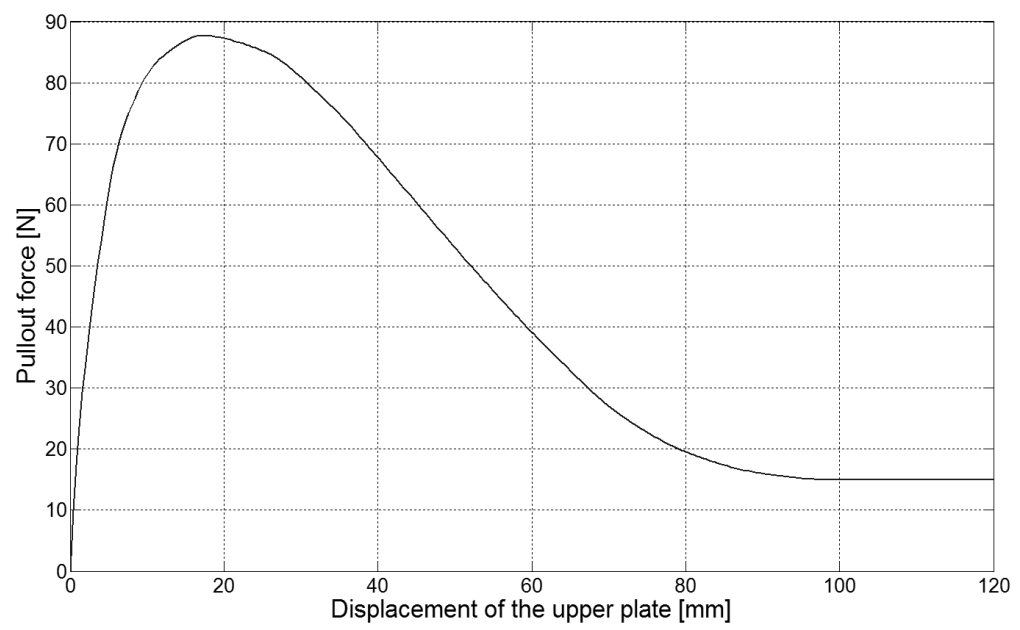

Fig. 5. Pull-out force versus displacement

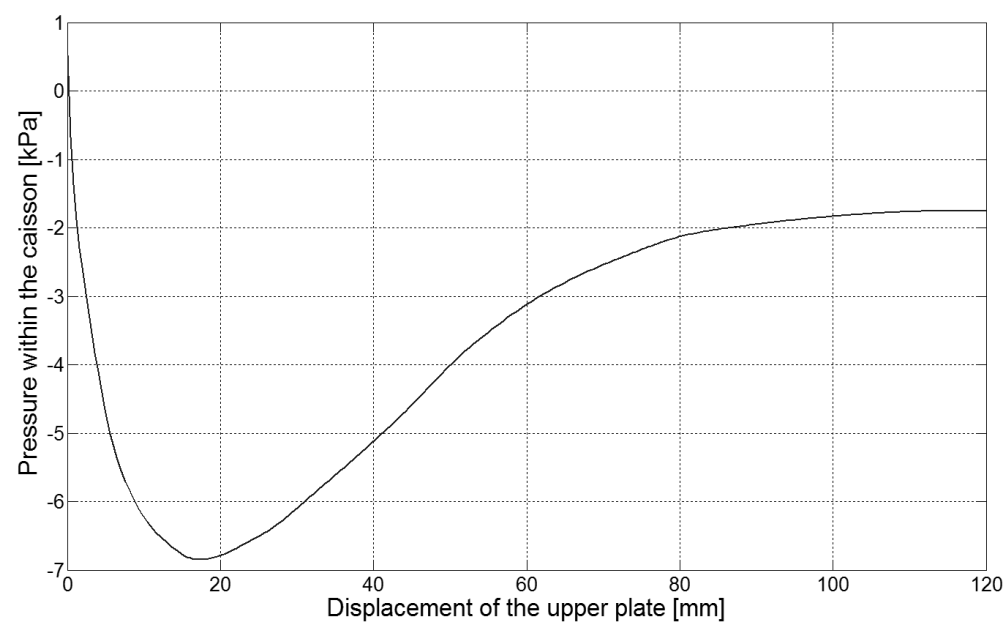

Fig. 6. Suction pressure versus displacement

Figure 5 shows a record of the pull-out load of the model against the caisson displacement, and Figure 6 shows the corresponding suction developed inside the model. Figures 7 and 8 present the pull-out force and suction results against time. It can be seen that suction and the pull-out force increased rapidly at the beginning 


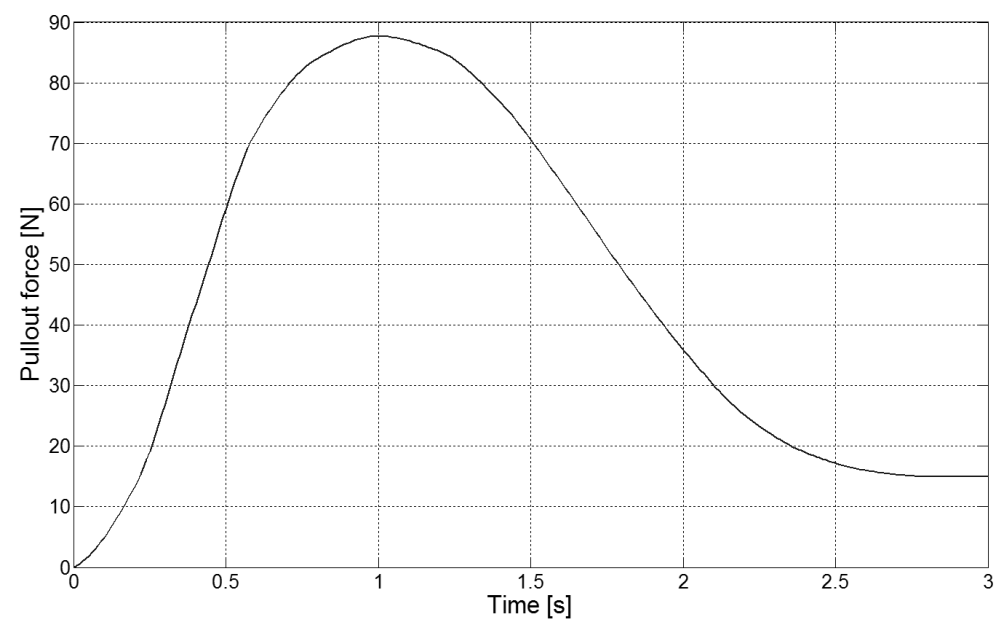

Fig. 7. Pull-out force versus time

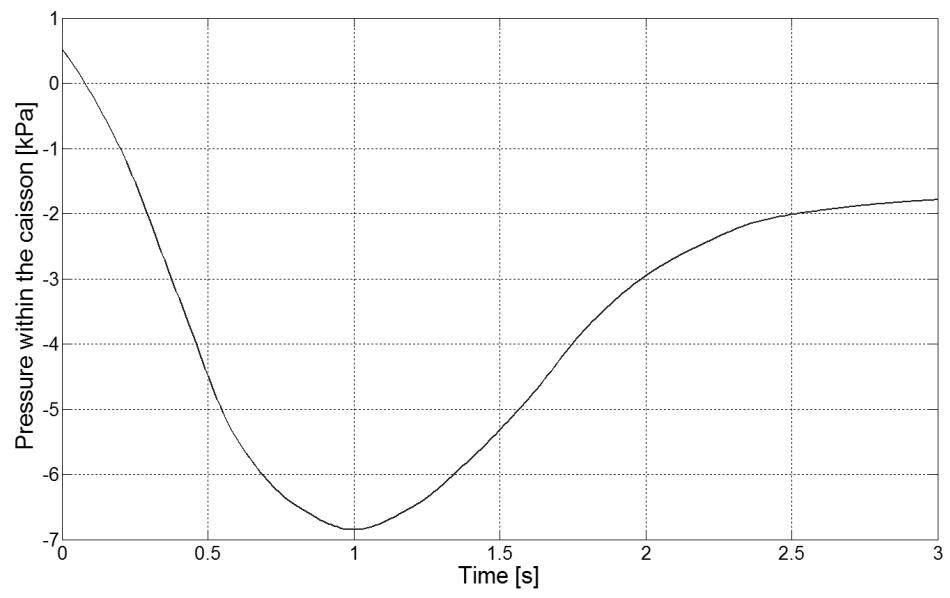

Fig. 8. Suction pressure versus time

of the extraction process, and then gradually decreased. The maximum of the tensile load and the maximum suction beneath the lid occurred at the same time. Both the pull-out force and the suction pressure reached their extreme values at 1 second of the experiment and at $18 \mathrm{~mm}$ displacement of the model. It should be noted that the slight overpressure recorded in the caisson at the beginning of the test (see Figures 6 and 8) was caused by ambient water pressure due to the $50 \mathrm{~mm}$ column of water above the sand surface.

After extraction, the model caisson was examined, e.g. weight, etc. It was observed that some soil had been pulled out together with the model caisson, see Figure 9. This 
means that the contact forces between the "intrinsic" soil and the cylindrical side wall of the caisson were quite large. The total weight of the caisson with extracted soil $G_{c s}$ measured after the experiment was $15 \mathrm{~N}$, and the average height $h_{s}$ of the extracted soil in the caissons was $37 \mathrm{~mm}$.

Table 2. Experimental results

\begin{tabular}{|l|c|}
\hline Maximum pull-out force $P$ & $87.1 \mathrm{~N}$ \\
\hline Maximum suction pressure $s$ & $6.76 \mathrm{kPa}$ \\
\hline Model displacement at the maximum force & $18 \mathrm{~mm}$ \\
\hline Height of extracted soil in the caisson $h_{s}$ & $37 \mathrm{~mm}$ \\
\hline Total weight of the caisson with extracted soil $G_{c s}$ & $15 \mathrm{~N}$ \\
\hline
\end{tabular}

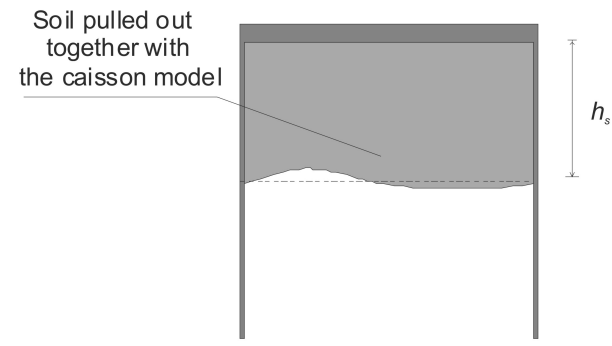

Fig. 9. Soil extracted with the model during the experiment

\section{Hypothetical Mechanism of Pull-out}

The following analysis concerns the extraction of suction caissons from the fully saturated subsoil (seabed). Suction caissons are frequently used in marine and offshore structures, where loadings applied to construction caissons vary, even in terms of direction. In the case of large environmental loads acting on the structure construction (i.e. wind, storm or waves), the resultant force may pull the foundation out the of the subsoil. In many practical applications, for example, during sudden wave loadings, the first stage of extraction is the most important, as it determines the bearing capacity of the suction caisson foundation. Waves and other environmental loadings are rapid, in contrast to those observed during some technological procedures, such as the removal of suction caissons.

Therefore the experiment performed in IBW PAN will be analyzed in the context of a hypothetical mechanism of pull-out, assumed after some preliminary investigations. Recall that our analysis deals with the first stage of extraction, characterized by the maximum pull-out force, which initiates this phenomenon. The analysis of large displacements in the subsequent stages of extraction is outside the scope of this paper. The hypothetical mechanism of pull-out assumed after our experiment is shown in Fig. 10. 


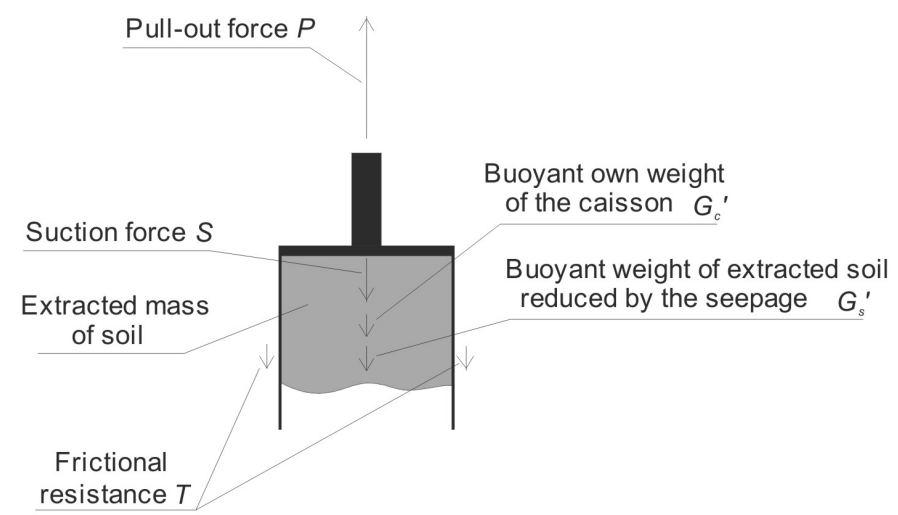

Fig. 10. A hypothetical mechanism of the suction caisson pull-out in the first stage of extracation

After the experiment, it was seen that a certain mass of soil had been extracted together with the model suction caisson. For our purposes, it is sufficient to note that the total weight of the extracted object consists of the weight of the suction caisson itself and that of the adherent soil mass. A consequence of this observation is that the internal friction between this extricated mass and the internal walls of the caisson does not play any role in the analysis.

The frictional resistance $T$ of the side walls can be determined by elementary methods. The main task is to determine the suction force $S$ between the circular plate closing the caisson from above and the saturated soil. This suction force is strictly related to the elastic unloading of the saturated subsoil, as described in (Sawicki 1995) and (Sawicki and Mierczyński 2003). In the present paper, this model will be applied to analyze the experimental results.

\section{A Simple Model of the Breakout Phenomenon ("IBW PAN" approach)}

In order to explain the phenomenon of breakout, let us consider the extraction of a heavy plate from the sea bottom, see Fig. 11 . This process is controlled by three forces, namely: $P=$ pull-out force, $G_{p}^{\prime}=$ buoyant own weight of the plate, and $S_{c}=$ resultant of suction forces. Experimental and in situ observations show that $P>G_{p}^{\prime}$. Therefore, the conclusion was drawn that suction forces should develop during the extraction process.

It was shown that the breakout force is given by the following formula, see (Sawicki 1995):

$$
S_{c}=k_{p} G_{p}^{\prime},
$$

where

$$
k_{p}=\frac{\kappa^{s}}{n_{0} \kappa^{f}},
$$




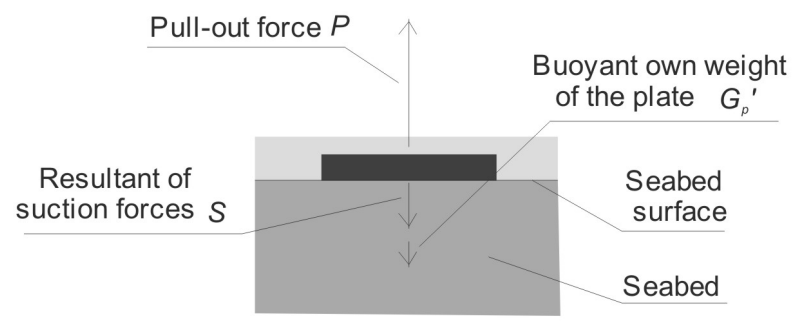

Fig. 11. A simple model of the breakout phenomenon for a heavy plate lying on the seabed, see (Sawicki 1995)

and $\kappa^{s}$ is an elastic compressibility of the soil skeleton, $\kappa^{f}$ is pore fluid compressibility, both in $\mathrm{m}^{2} / \mathrm{N}$ and $n_{0}$ denotes the initial porosity of the seabed.

It is a very simple formula, as the suction coefficient $k_{p}$ depends on only two, apparently obvious, parameters, namely the compressibilities of the soil skeleton and pore fluid. From the practical point of view, the determination of these parameters is difficult, and in soil mechanics there is still no consensus as to their meaning and methods of determination. It is the subject of a broader discussion on soil parameters, which is not the aim of this paper. Our current knowledge is sufficient for very rough estimations only. Table 3 illustrates the values of the suction coefficient (in bold)for several combinations of the above-mentioned compressibilities (Sawicki 1995).

Table 3. The suction coefficient $k_{p}$ as a function of different values of $\kappa^{s}$ and $\kappa^{f}$

\begin{tabular}{|c|c|c|c|c|c|}
\hline \multirow{2}{*}{$\begin{array}{c}\text { Degree of } \\
\text { aeration } \\
{[\%]}\end{array}$} & \multirow{2}{*}{$\begin{array}{c}\text { Pore fluid } \\
\text { compressibilities } \\
\kappa^{f} \\
{\left[\mathrm{~m}^{2} / \mathrm{N}\right]}\end{array}$} & \multirow[t]{2}{*}{$\kappa^{f} \cdot n_{o}$} & \multicolumn{3}{|c|}{$\begin{array}{l}\text { Soil skeleton compressibilities } \\
\qquad \kappa^{s}\left[\mathrm{~m}^{2} / \mathrm{N}\right]\end{array}$} \\
\hline & & & $\begin{array}{c}\text { gravel } \\
10^{-9}\end{array}$ & $\begin{array}{l}\text { sand } \\
10^{-8}\end{array}$ & $\begin{array}{l}\text { clay } \\
10^{-7}\end{array}$ \\
\hline $0.00 \%$ & $0.5 \cdot 10^{-9}$ & $2 \cdot 10^{-10}$ & 5 & 50 & 500 \\
\hline $0.05 \%$ & $2.5 \cdot 10^{-9}$ & $10^{-9}$ & 1 & 10 & 100 \\
\hline $0.50 \%$ & $2.5 \cdot 10^{-8}$ & $10^{-8}$ & 0.1 & 1 & 10 \\
\hline
\end{tabular}

Note that pore water compressibility increases with the degree of aeration. For example, for $0 \%$ aeration, $\kappa^{f}=0.5 \times 10^{-9} \mathrm{~m}^{2} / \mathrm{N}$, and for only $1 \%$ aeration, this figure increases by two orders of magnitude. An average compressibility of sand is of the order of $\kappa^{s}=10^{-8} \mathrm{~m}^{2} / \mathrm{N}$. Therefore, the values of the suction coefficient presented in Table 3 may serve only as rough estimates.

\section{Comparison with Experimental Data}

Let us consider our experiment, performed with a typical caisson. The own weight of this model was $G_{c}=9.6 \mathrm{~N}$, and the maximum extracation force was $P=87.1 \mathrm{~N}$.The total weight of the caisson with fully saturated extracted soil was about $G_{c}+G_{s}=$ $15.0 \mathrm{~N}$, and hence the weight of the extracted sand was $G_{s}=15.0-9.6=5.4 \mathrm{~N}$. 
It should be noted that in extraction process the porewater seepage induced by the suction forces occurs around the caisson wall. This seepage reduces the buoyant weight of the extracted soil inside the caisson. In this case the resultant suction force $S_{c}$ is given by the following formula, c.f. Figure 10:

$$
S_{c}=P-\left(G_{c}^{\prime}+G_{s}^{\prime}+T_{o}+T_{i}\right),
$$

where $G_{c}^{\prime}$ the buoyant own weight of the caisson, $G_{s}^{\prime}$ is the buoyant weight of the extracted soil reduced by the seepage and $T_{o}$ and $T_{i}$ are friction resistance forces along the exterior and interior caisson wall surfaces, respectively.

The buoyant weight of the extracted soil reduced by the seepage $G_{s}^{\prime}$ given by a formula:

$$
G_{s}^{\prime}=G_{s}\left[1-\frac{(1+i) \gamma_{w}}{\gamma_{s a t}}\right],
$$

where $i$ is average hydraulic gradient inside the caisson, $\gamma_{w}$ is the unit weight of water $\left(\gamma_{w}=10 \mathrm{kN} / \mathrm{m}^{3}\right)$, and $\gamma_{s a t}$ is the unit weight of saturated sand $\left(\gamma_{s a t}=19.7 \mathrm{kN} / \mathrm{m}^{3}\right.$, see Table 1).

The value of $G_{c}^{\prime}$ can be obtained from the expression:

$$
G_{c}^{\prime}=G_{c}\left(1-\frac{\gamma_{w}}{\gamma_{s t}}\right)
$$

where $\gamma_{s t}$ is the unit weight of steel $\left(\gamma_{s t}=78.5 \mathrm{kN} / \mathrm{m}^{3}\right)$.

The total friction resistance along the side wall $T$ can be calculated from the expression, c.f. Houlsby et al (2005b):

$$
T=\left(T_{o}+T_{i}\right)=\frac{\gamma^{\prime} h^{2}}{2}(K \tan \delta) \pi D_{o}+\frac{\gamma^{\prime} h_{i}^{2}}{2}(K \tan \delta) \pi D_{i},
$$

where $h_{i}=h-h_{s}=63 \mathrm{~mm}$ (c.f. Figure 9), $\gamma^{\prime}$ is the effective weight of the soil ( $\gamma^{\prime}=$ $\gamma_{\text {sat }}-\gamma_{w}=9.7 \mathrm{kN} / \mathrm{m}^{3}$ ), and $K$ is a coefficient of lateral earth pressure, which, in the case of caisson walls, can be calculated from the following formula, see (Zeevaert 1983, Handy 1985 and Villalobos 2007):

$$
K=\frac{2 \cdot \cos ^{2} \phi}{\cos ^{2} \phi} .
$$

For the experimental data, the coefficient $K=1.91$, and the total friction resistance along the side wall was $T=7.1 \mathrm{~N}$. In order to estimate the value of the average hydraulic gradient inside the caisson, a flow net was determined numerically for experimental data, see Fig. 12. In this case $i=0.4$ and the buoyant weight of the extracted soil was $G_{s}^{\prime}=1.56 \mathrm{~N}$. The total buoyant weight of the extracted object was $G_{c}^{\prime}+G_{s}^{\prime}=8.38+1.56=9.94 \mathrm{~N}$. The resultant suction force in this case was $S_{c}=87.1-9.94-7.1=70.1 \mathrm{~N}$. The corresponding suction coefficient, calculated from Eq. (1), is therefore $k_{p}^{\text {exp }}=70.1 \mathrm{~N} / 9.94 \mathrm{~N}=7.05$. 


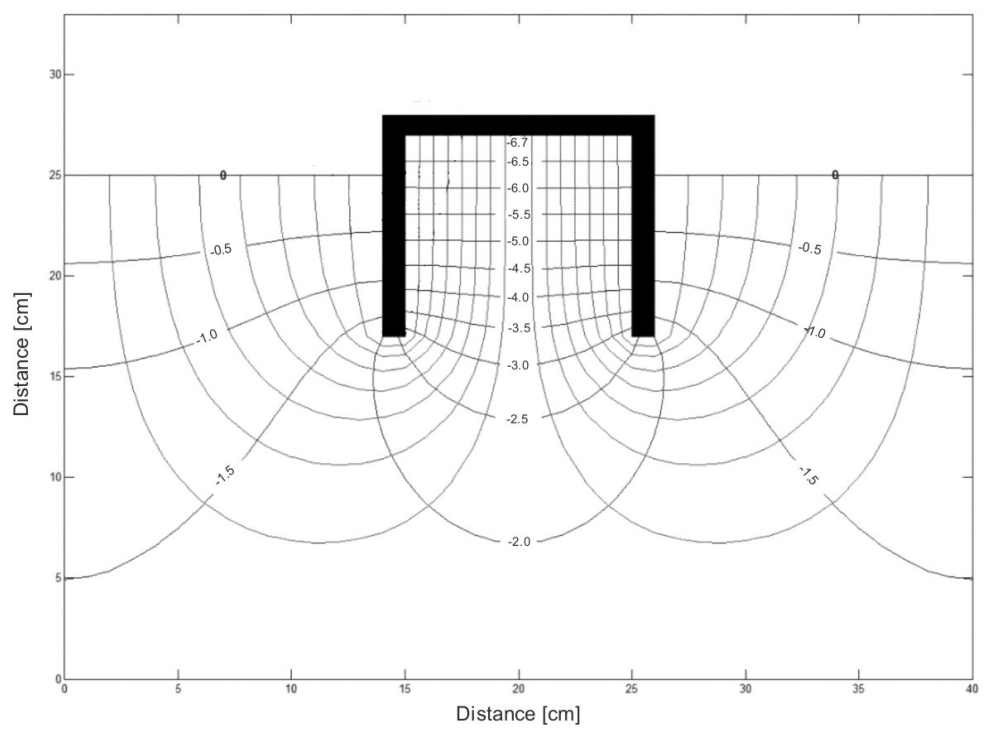

Fig. 12. The section through the model and the flow net determined for experimental data

It is a realistic result, as compared with the values shown in Table 3. It roughly corresponds to sand with slightly de-aerated pore water, that is, still containing some gas, which was not controlled during the experiment.

The calculation procedure for predicting the pull-out capacity of a suction caisson is very simple. In the first step, the submerged own weight of the caisson and the saturated soil inside it should be calculated. In the second step, the friction resistance along the side wall $T$ can be determined from Eq. (6). The next step is to estimate the suction coefficient $k_{p}$, corresponding to the soil type and the aeration of pore water, see Table 1. Finally, the suction force $S_{c}$ should be determined from Eq. (1), and the pull-out force $P$ should be calculated from Eq.(8):

$$
P=S_{c}+G_{c}^{\prime}+G_{s}^{\prime}+T_{o}+T_{i}
$$

For data corresponding to our experimental conditions, we have: $S_{c}=k_{p}\left(G_{c}^{\prime}+\right.$ $\left.G_{s}^{\prime}\right)=10(8.38+1.56)=99.4 \mathrm{~N}, s=\left(4 S_{c}\right) / \pi D_{i}^{2}=13.5 \mathrm{kPa}, T=\left(T_{o}+T_{i}\right)=7.1 \mathrm{~N}$, and finally $P=116.4 \mathrm{~N}$. Recall that the experimental pull-out force was $81.7 \mathrm{~N}$.

The above difference between the theoretical and experimental results arises from the simplicity of the theoretical approach and estimation of the basic soil properties. However, despite these differences, the experimental results and the theoretical prediction seems to be comparable.

\section{Comparison with the Houlsby et al Solution ("Oxford" Approach)}

A different approach to predicting the tensile capacity of a suction caisson under rapid loading, presented by Houlsby et al (2005) from the Department of Engineering 
Science, Oxford University, was compared with the IBW PAN experimental results. Those authors proposed calculation procedures for predicting the suction within the caisson and then for calculating the pull-out load. Different cases were considered, such as the presence or absence of the process of cavitation in water and of soil liquefaction inside the caisson. Houlsby et al found that predictions of suction and the pull-out load depended significantly on the rate of extraction and on the ambient pore pressure.

The IBW PAN experiment was conducted at a pull-out rate of $v=20 \mathrm{~mm} / \mathrm{s}$ and at a relatively small ambient pressure (atmospheric plus $0.5 \mathrm{kPa}$ ). Under these conditions, the pull-out rate was such that suction was sufficiently small, so it could be assumed that cavitation did not occur. Hence, the procedure appropriate in the absence of cavitation and liquefaction was applied. The following equations were proposed by Houlsby et al in this case:

$$
s=\frac{\pi}{4 F} \frac{D_{i} \gamma_{w}}{k_{0}} v
$$

and

$$
P=s \frac{\pi D_{i}^{2}}{4}+G_{c}^{\prime}+G_{s}^{\prime}+\left[\left(\gamma^{\prime}+\frac{a s}{h}\right) \frac{\pi D_{o} h^{2}}{2}+\left(\gamma^{\prime}+\frac{(1-a) s}{h_{i}}\right) \frac{\pi D_{i} h_{i}^{2}}{2}\right] K \tan \delta,
$$

where $s$ is the pressure in the caisson, $F$ is a dimensionless factor, and $a$ is a pressure factor. The factor $F$ can be calculated from the following equation:

$$
F=\frac{3.6}{1+5 \frac{h}{D_{i}}}
$$

The factor $a$ represents the ratio of the excess pore fluid pressure at the tip of the caisson skirt to the beneath the base $(0 \leq a \leq 1)$, which, for a soil of uniform permeability, can be approximated by:

$$
a=c_{0}-c_{1}\left[1-e^{-\frac{h}{c_{2} D_{i}}}\right],
$$

with the values $c_{0}=0.45, c_{1}=0.36$ and $c_{2}=0.48$.

For the IBW PAN experimental data, $F=0.59$ and $a=0.132$. The value of suction inside the caisson, obtained from Eq.(9), is $s=16.76 \mathrm{kPa}$, so the corresponding suction force is $S_{c}=s\left(\pi D^{2} / 4\right)=123.8 \mathrm{~N}$. The pull-out capacity calculated from Eq.(10) is $P=123.8 \mathrm{~N}+8.38 \mathrm{~N}+1.56 \mathrm{~N}+64.3 \mathrm{~N}=198.0 \mathrm{~N}$.

The measured and predicted maximum values of pull-out loads and suction pressures for the "IBW PAN" and "Oxford" theories are shown in Table 4.

The level of correspondence between theoretical predictions and experimental measurements seemed to be acceptable despite some differences. It should be noted that the "IBW PAN" method provides a more accurate estimation of the pull-out load 
Table 4. Measured and predicted pull-out loads and suction pressures

\begin{tabular}{|c|c|c|c|}
\hline \multirow{2}{*}{ Parameter } & \multicolumn{3}{|c|}{ Results } \\
\cline { 2 - 4 } & Measured & \multicolumn{2}{|c|}{ Predicted } \\
\cline { 3 - 4 } & "IBW PAN" & "IBW PAN" & "Oxford" \\
\hline Pull-out load & $87.1 \mathrm{~N}$ & $116.4 \mathrm{~N}$ & $198.0 \mathrm{~N}$ \\
\hline Suction pressure & $6.76 \mathrm{kPa}$ & $13.50 \mathrm{kPa}$ & $16.76 \mathrm{kPa}$ \\
\hline
\end{tabular}

and suction pressure inside the caisson obtained in the experiment performed by IBW PAN.

\section{Discussion and Conclusions}

The results reported in this paper can be summarized as follows:

a. The IBW PAN model of an axially-symmetric extraction of suction caissons seems to be the simplest and most realistic, at least during the first stage of this phenomenon. It assumes that the pull-out resistance is determined mainly by suction forces, together with a relatively small friction along the side walls of the caisson. The model is restricted to rapid extraction, when the filtration phenomenon and the associated re-grouping of pore water pressures are neglected. This means that the predictions of the model are the upper-bound estimates of the pull-out resistance, which is important from the engineering point of view, when the loadings applied are also rapid.

b. The agreement between the IBW PAN experimental results and model predictions is reasonable. Our solution gives results which are closer to experimental than those obtained with the "Oxford" theory. Despite some differences between the experiment and both theories, the order of magnitude of the pull-out load and the suction force is correctly predicted in all cases.

c. It should be noted that in geotechnical investigations a complete agreement between experimental results and various models is impossible, as the basic soil properties are always estimated. From this point of view, our approach is rational, as we provide some estimates that can be useful in engineering applications.

d. An advantage of the method presented is that it is formally simple and straightforward. No complex calculations are necessary to estimate the pull-out capacity of suction caissons under axi-symmetric conditions. A much more complex analysis is necessary when the pull-out force is inclined with respect to the vertical direction.

e. The results presented can be applied in practice for a quick first estimation of the pull-out force. In the first step of such an analysis, the submerged own weight of the caisson and the friction resistance along the side wall should be calculated. In this step,the possible extraction of soil should be taken into account. The second step is to estimate the suction coefficient corresponding to the soil type and the aeration of pore water. Finally, the suction force and pull-out force should be determined from Eq. (1) and Eq. (8), respectively. 


\section{Acknowledgement}

The research reported in this paper was supported by the MERMAID program of the European Union. Some of these investigations were conducted as part of the mission-related research of IBW PAN.

\section{References}

Byrne B. W., Houlsby G. T. (2002) Experimental investigations of response of suction caissons to transient vertical loading, Journal of Geotechnical \& Geoenvironmental Engineering, ASCE, 128 (11), 926-939.

Cao J., Phillips R., Popescu R., Audibert J. M. E., Al-Khafaji (2002) Numerical analysis of the behavior of suction caissons in clay, Proc. 12th International Offshore and Polar Engineering Conference, Kitakyushu (Japan), 795-799.

Chen W., Randolph (2007) Uplift capacity of suction caissons under sustained and cyclic loading in soft clay, Journal of Geotechnical \& Geoenvironmental Engineering, ASCE, 133 (11), 1352-1363.

Gabr M. A., Xiao J., Rahman M. S. (2015) Plastic flow of sand and pullout capacity of suction caissons, Technical Breakthrough Abstract, Journal of Geotechnical \& Geoenvironmental Engineering, ASCE, 02815002-1.

Handy R. L. (1985) The arch in soil arching, Journal of the Geotechnical \& Engineering Division, ASCE, 111 (3), 302-318.

Houlsby G. T., Byrne B. W. (2005) Design procedures for installation of suction caissons in sand, Proc. ICE, Geotechnical Engineering, 158, GE3, paper 13818, 135-144.

Houlsby G. T., Kelly R. B., Byrne B. W. (2005) The tensile capacity of suction caissons in sand under rapid loading, Proc. Int. Symposium on Frontier in Offshore Geotechnics, ISFOG, Perth, 405-410.

Houlsby G. T., Kelly R. B., Huxtable J., Byrne B. W. (2005) Field trials of suction caissons in clay for offshore wind turbine foundations, Geotechnique, 55 (4), 287-296.

Huang J., Cao J., Audibert J. M. E. (2003) Geotechnical design of suction caissons in clay, Proc. 13th International Offshore and Polar Engineering Conference, Honolulu (USA), 770-777.

Jara F. A. V. (2009) Foundations for offshore wind turbines, Revista Ingenieria de Construccion, 24 (1), 33-48.

NGI (I): Skirted caisson foundations for offshore structures, www.ngi.no.

NGI (II): Suction anchor installation, www.ngi.no.

Patel S. K., Singh B. (2012) Study on installation and pullout of suction caisson foundation for offshore wind turbines, SAITM Research Symposium on Engineering Advancements, 39-42.

Sawicki A. (1995) Soil suction forces and the breakout phenomenon, Studia Geotechnica et Mechanica, XVII (1-2), 5-21.

Sawicki A., Mierczyński J. (2003) Mechanics of the breakout phenomenon, Computers \& Geotechnics, 30, 231-243.

Villalobos F. (2007) Installation of suction caissons in sand, Proc. VI Congreso Chileno de Geotecnia, Valparaiso, 13 pages.

Zeinoddini M., Nabipour M. (2009) A parametric study on the pull-out response of suction caissons, Journal of Marine Engineering, 5 (9), 1/E-16/E.

Zeevaert L. (1983) Foundation engineering for difficult subsoil conditions, Second edition, van Nostrand Reinhold. 